\title{
Residential Photovoltaic Systems in Norway: Household Knowledge, Preferences and Willingness to Pay
}

\author{
Todd L. Cherry ${ }^{1,2, *}$ and Hanne Sæle ${ }^{3}$ \\ ${ }^{1}$ CICERO Center for International Climate Research, Oslo, Norway \\ ${ }^{2}$ Appalachian State University, North Carolina, USA \\ ${ }^{3}$ Department of Energy Systems, SINTEF Energy Research, Trondheim, Norway \\ * Corresponding author: E-Mail: cherryt|@appstate.edu; Tel.: +1 8282622148.
}

Submitted: 5 July 2019 | In revised form: | Accepted: 31 December 2019 |

Published: 8 April 2020

\begin{abstract}
Solar power or photovoltaic (PV) systems have emerged as a leading low-carbon energy technology worldwide, but the deployment of residential PV systems in Norway has lagged behind other Scandinavian countries. Therefore, the Norwegian market provides an opportunity to gain insights on the demand factors that determine residential PV adoption. This paper presents results from a statedpreference survey designed to elicit household knowledge, preferences and willingness to pay for residential PV systems. Results suggest that meaningful growth in residential PV capacity depends greater knowledge among households, continued advances in technology, clarity with the grid tariff and stronger support systems. A review of recent experiences in the field corroborates the important role of effective regulatory structures and support programs.
\end{abstract}

Keywords: Norway; prosumers; renewable; residential photovoltaic

\section{Introduction}

Solar power or photovoltaic (PV) systems have emerged as a leading low-carbon energy technology. Two decades of growth have led to the cumulative global deployment of more than $303 \mathrm{GW}$ of PV capacity, with over half of this capacity being installed since 2013 [1]. The recent surge in PV installed capacity has rebalanced the PV market in a couple of ways. First, the PV market is becoming more global. Until 2013, Europe accounted for over 70 percent of cumulative PV capacity, but it now has less than 45 percent. By 2015, two-thirds of cumulative installed capacity had expanded to China, Germany, Japan and the U.S., and trends in annual installations indicate strong growth in new markets, including India, U.K. and Australia. The second shift in the PV market is that installed capacity is becoming larger and more centralized. Prior to 2011, utility-scale centralized installations accounted for less than 25 percent of annual installed capacity, but since 2013 , it has accounted for more than half of annual deployment [2].

Even as utility-scale PV develops, decentralized PV systems remain an important segment of the PV market, approaching $76 \mathrm{GW}$ in 2017 [1]. A promising development for this segment of the market is the emergence of PV prosumers-active energy consumers that both consume and produce electricity. Prosumers include homeowners, cooperatives, and housing associations that produce electricity at home, typically using residential PV systems [3]. Though a few prosumers are off the grid, nearly all prosumers generate power while remaining connected to the grid. This group, 
by generating power, can reduce the amount of power they purchased from the grid, and often get remunerated for surplus generation delivered to the grid.

The development of the prosumer market is shaped by the mix of market, technology and policy factors, such as declining solar PV costs, smart-grid technology, feed-in-tariffs, net-metering, etc. [3]. Early experiences with prosumers have created optimism and concern. While there is enthusiasm about the potential growth in PV prosumers, this growth is likely to be disruptive to the traditional centralize utility-scale industry [3]. Policymakers therefore face difficult tradeoffs in developing incentives and rules for the PV prosumer market [4]. To better navigate these tradeoffs, policymakers need greater understanding of the policy elements that help shape the PV prosumer landscape and determine its future.

This study seeks to contribute to this need by investigating consumer preferences related to PV prosumer adoption; thereby offering new insights that can inform more effective and efficient PV programs and policies. Herein we report findings from a study of Norwegian households that was designed to uncover the factors that shape demand for residential PV systems. Norway provides a promising case study because its residential PV capacity is underdeveloped relative to its neighbors (Denmark and Sweden). The potential for growth is heightened by Norwegian households being aware and responsive to environmental and energy issues. This unique setting offers new openings for understanding residential demand, particularly the role of non-material concerns, such as sustainability, environmental quality and social justice. Findings indicate that household interest in renewable energy is significantly influenced by non-material concerns, primarily those related to the environment. These concerns appear to have a limited effect on household decisions to purchase residential PV systems. Results show that people generally have not considered installing a residential PV system because they were unaware of the potential, satisfied with the current power system, and concerned about the cost. However, a recent surge in PV development illustrates the importance of support programs and regulatory rules. Findings provide new insights on the individual preferences that shape demand for PV systems, including the interplay between preferences and support programs.

The paper consists of five sections. After the introduction, section two describes the development of residential PV and prosumers in Norway and Scandinavia. Section three provides a review of the relevant literature, while section four describes the study's methods. Results and concluding remarks are resented in sections five and six.

\section{The development of PV in Scandinavia}

While Europe led PV development until 2013, the development was concentrated in Germany and Italy. Scandinavia-Denmark, Norway and Sweden-had shown little interest in solar PV. This changed in 2012 when Denmark established a net-metering system that led to rapid growth in PV prosumer installations. This growth however was dampened after policymakers modified the net-metering system, and recent PV development has shifted to centralized utility-scale capacity [5]. The Denmark case illustrates the important role that regulatory incentives have on $\mathrm{PV}$ prosumer development.

Sweden has experienced steady growth in PV capacity since 2010, albeit slower than Denmark. The Swedish PV market consists largely of decentralized installations. Initial deployments consisted of off-grid capacity that served recreation cabins, but grid-connected decentralized capacity has become more common over the past 10 years [6]. The Swedish market has benefited from programs that provide a direct subsidy for installation, and while there is no net-metering system, compensation for the excess power of prosumers is provided by some utilities. Norway also has an off-grid market, but deployment has lagged behind Sweden. The Norwegian off-grid market is poised to grow due to the improved technology and availability of PV panels. In particular, $\mathrm{PV}$ system are expected to have a role in the development of micro-grid power systems on islands, which are transitioning to localized solutions that avoid costly infrastructure investments (e.g., replacing aging sea cables).

Norway has adopted solar PV at a slower pace than the other Scandinavian countries. In 2018, cumulative PV capacity in Sweden and Denmark reached $426 \mathrm{MW}$ and 991 MW, while Norway approached only 68 MW [6-8]. Norway's slow adoption of PV may be explained by the structure of the country's power system. In Norway (2018), 95 percent of the electric energy is produced by hydro power, 2.6 percent is produced by wind power and 2.4 percent is produced by thermal power plants [9]. In Demark (2017), approximately 47 percent of the electric energy is generated by wind and 50 percent from conventional thermal power plants [10]. Sweden generates approximately 37 percent of electricity with hydro plants, 37 percent from nuclear power plants, and 9 percent by conventional thermal power plants [11]. Norway's extensive reliance on low-cost hydro power likely mitigates interest in PV and other alternative energy sources. Solar irradiance is another factor that varies across Scandinavian countries.

Locations that enjoy the best solar resources have solar irradiances up to $2500 \mathrm{kWh} / \mathrm{m}^{2}$ per year (measured on a horizontal surface). Solar irradiances in Norway, with its substantial north-south distance, varies a great deal. In the south, where the population is skewed, the solar irradiance is approximately $1000 \mathrm{~kW} \mathrm{~h} / \mathrm{m}^{2}$ per year. In the north, it is about $700 \mathrm{~kW} \mathrm{~h} / \mathrm{m}^{2}$ per year [12]. Given that regions of Norway have similar solar irradiance than Sweden and Denmark, there is potential for Norway to gain ground with additional PV development [12].

$A$ recent surge in $P V$ installed capacity indicates that Norway is beginning to realize its PV potential. Indeed, 60 percent of the country's cumulative capacity has been installed since 2017 [8]. Norway's PV expansion has been driven by new rules, enacted in 2016, establishing clar- 
ity in the regulatory structures of net-metering and green certificates [13]. Specifically, Norway boosted residential rooftop solar with the "Plusskundeordningen" (Plus Customer) scheme that requires utilities to purchase power from prosumers-a utility customer with both consumption and generation behind the connection point to the grid [11]. Ten years earlier, the Norwegian regulator (NVE) opened the door for Distribution System Operators (DSOs) to purchase electricity from prosumers, but it was not mandatory for the DSOs [14,15]. In addition to the new policy for prosumers, economic measures providing new incentives to encourage prosumer adoption have been developed. For example, from January 2016, owners of small PV panels with an installed capacity below $15 \mathrm{kWh}$ are eligible for financial support from the public agency Enova SF [16]. Also, while the green certificate program initially supported prosumer generation delivered to the grid, the scheme was extended to support all electricity generation from prosumers.

\section{Literature Review}

Though the growth of PV and prosumers in Norway has lagged behind other Scandinavia countries, recent research offers insights on the potential for further development. One such study provides an excellent review by examining the historical development of prosumers in Germany, UK and Norway [17]. The study identifies the major determinants of prosumer activity by considering three types of factors: economic incentives (e.g., support schemes, tax benefits, etc.), regulatory structure (e.g., building codes, metering requirements, etc.) and access to information and installer markets (e.g., information campaigns, process assistance, etc.). Results indicate that support schemes play an important role in determining prosumer activity, with information and assistance also influencing activity. While decarbonization has been an issue in Germany and the U.K., this was not the case in the hydro power context of Norway. The paper offers a framework for possible pathways to PV and prosumer development:

- technical testing and pilot schemes (helping reducing local bureaucratic hurdles),

- establishment of a third-party installer marked (reducing transaction costs for potential prosumers), and

- transition to a mass market (PV-installation companies proliferate, generating practical information and further reducing transaction costs).

Using the development of smart grids, many efforts have examined alternative methods to engage energy users, such as feedback technologies, price tariffs and automated systems for load control. However, the literature would benefit from additional work on the socio-technical influences of PV and prosumer development [18]. Customer preferences are shaped by social and technological developments, which in turn dictate public support and consumer adoption [19].

A recent review of studies that examine individual preferences related to renewable energy finds little evidence on the specific case of PV and prosumers [19]. A study of British households finds that household willingness to pay is not sufficiently large to cover the high capital costs of micro-generation energy, including $P V$, even when considering annual cost savings [20]. Similarly, in a Republic of Ireland study, researchers investigated how the awareness of microgeneration technologies affected investment in microgeneration technologies. The findings reveal considerable variation in the awareness of alternative technologies, with awareness being greatest for PV. Consistent with previous studies, findings also report that awareness differs across socio-economic groups, with less awareness being observed among women and young people [21]. A study of German consumers indicates the motivation for microgeneration technologies is not only using green electricity and a profitable investment in new technology, but also the possibility for using their own produced electricity [22]. Greater insights on customers' knowledge and preferences are needed to understand the development of prosumers. This study seeks to contribute to this need.

\section{Methodology}

We conducted an online survey with a representative sample of Norwegian households. It was administered to a panel operated by TNS Gallup between March and May of 2016. This panel consists of approximately 45,000 persons (15 years and older) recruited in advance to participate in surveys. Respondents to the survey were randomly selected from this group. The survey targeted 1000 completed surveys. To that end, an invitation to participate in the survey was sent via email to 2000 people in the panel with 1128 responding and 1102 completing the survey. The survey closed when it reached 1000 completed responses, which precluded tardy responders from an opportunity to participate.

The objectives of the survey are twofold: (i) assess the preferences, perceptions and activities related to residential electricity, and (ii) estimate the total value (including non-use) associated with residential PV systems. The data speaks to the demand side factors that present barriers and opportunities for prosumer development, including the willingness to pay for residential PV systems. The survey design relates to the Norwegian case but the basic framework follows a standard design that can be extended to other populations.

The survey consisted of four sections, as presented in Table 1. The first section solicited information on general perceptions about household electricity usage. Specifically, respondents were asked to indicate their level of concern and knowledge about general household electricity issues. Also, respondents were asked to give an estimate on their relative use of electricity for household activities-appliances, lights and air and water heating.

The second section focused on consumer knowledge and attitudes about domestic electricity production. After introducing the prosumer concept and technology, respondents were asked if they were a prosumer. For non-prosumers, the survey asked respondents the level of their knowledge about prosumer systems, the reasons for not installing a system, and their level of confidence about being satisfied with a prosumer 
system. For prosumers, the survey asked respondents how they learned about prosumer systems, how long they have had a system, the reasons for installing a system, and their satisfaction with their prosumer system. The analysis focuses on barriers and opportunities, which draws from responses of those without a solar system. Nearly all respondents did not have a solar system (98.9\%). Among those, most had not considered installing a system (72.9\%). Only 1.1 percent of respondents (12 of 1102) had a PV system at the time of the survey, with just 3 of the 12 having a system that feeds electricity to the grid (i.e. being a prosumer). Figure 1 illustrates the flow chart of the survey and reports the number of respondents within each sub-group. Section three elicited consumer preferences concerning the installation of a prosumer system, which included stated-preferences that allow the estimation of household willingness to pay (WTP). WTP is the maximum amount a customer is willing to pay for a good or service and represents the total value that a person has for a good or service. We employ the contingent valuation method to estimate WTP-a standard approach that creates a hypothetical market in which people can indicate their preferences and willingness to pay. The method has been used over the last few decades to estimate the total value of many items such as public parks, downtown beautification projects, ecosystem preservation, and health risks [23,24]. We apply this technique to estimate the total value of the benefits associated with a residential PV system. To focus on current demand among non-prosumers, this section was not delivered to the small number of existing prosumers in the sample.

We note that, while actual sales data is useful, it's limited in estimating customer demand. Sales data only captures activity at a given price or range of prices, which fails to reflect the entirety of customer demand. Some customers are willing to pay a price lower than the current market price, while others are willing to pay a price above the current market price. Also, sales data often fails to adequately capture the social benefits or costs associated with the product, such as the environmental benefits associated with renewable energy. This component of customer value may be significant for PV and other renewable technologies.

Following established designs in the valuation literature $[25,26]$, this section first introduced a realistic contingent market with the following script: "Now consider a hypothetical Prosumer Electricity Program that is based on actual programs offered by many governments/utilities. With the hypothetical Prosumer Electricity Program, the utility/government would offer their customers the opportunity to install a home electricity generation system at their home to generate electricity themselves. Customers could use the electricity they produce and sell any remaining electricity to others through the grid."

Using standard stated-preference methods, we adopted a referendum payment vehicle similar to previous studies [25,26]: "Households that choose to install a home electricity generation system would pay a one-time fee of A NOK (Norwegian currency). [27] The fee would cover the installation, including materials and labor. If given a chance, would you participate in the program?" The fee was randomly assigned to respondents and took on one of four values: $A$ $=20,000,40,000$ and 60,000. To improve estimation efficiency, the three values correspond to realistic household willingness to pay values. Also, while estimation is more demanding with the dichotomous choice referendum, it is incentive compatible with actual preference and therefore preferred to open-ended questions [28,29]. Follow-up questions asked respondents about how certain they were about their yes or no response to the participation question and what were the most important reasons for their willingness (yes or now) to participate in the program.

The fourth and final section, as illustrated in Table 1, collected general information on individuals and households, such as socio-economic, household type/location, etc.

Table 1. Summary of survey design.

\begin{tabular}{ll}
\hline $\begin{array}{l}\text { 1. General perspectives about } \\
\text { household electricity usage }\end{array}$ & $\begin{array}{l}\text { Concern related to the electricity consumption of the household. Knowledge about sources used for } \\
\text { electricity generation in Norway. Knowledge about electricity consumption at Norwegian households. }\end{array}$ \\
\hline 2. Electricity produced with PV system & $\begin{array}{l}\text { Questions if the customer has a PV system, or has considered installing? Asking about reasons for } \\
\text { considering or not considering installing PV. Asking about how secure/insecure they are related to } \\
\text { considering or not considering installing PV. }\end{array}$ \\
\hline 3. Willingness to pay & $\begin{array}{l}\text { Respondents divided in three groups asking if they wanted to install a PV system at the given price, } \\
\text { and how secure/insecure they are about this. Asking about reasons/interests for installing in a PV } \\
\text { system. }\end{array}$ \\
\hline $\begin{array}{l}\text { 4. General information on individuals } \\
\text { and households }\end{array}$ & Socio-economic, household type/location, income, education level, number of persons, etc \\
\hline
\end{tabular}




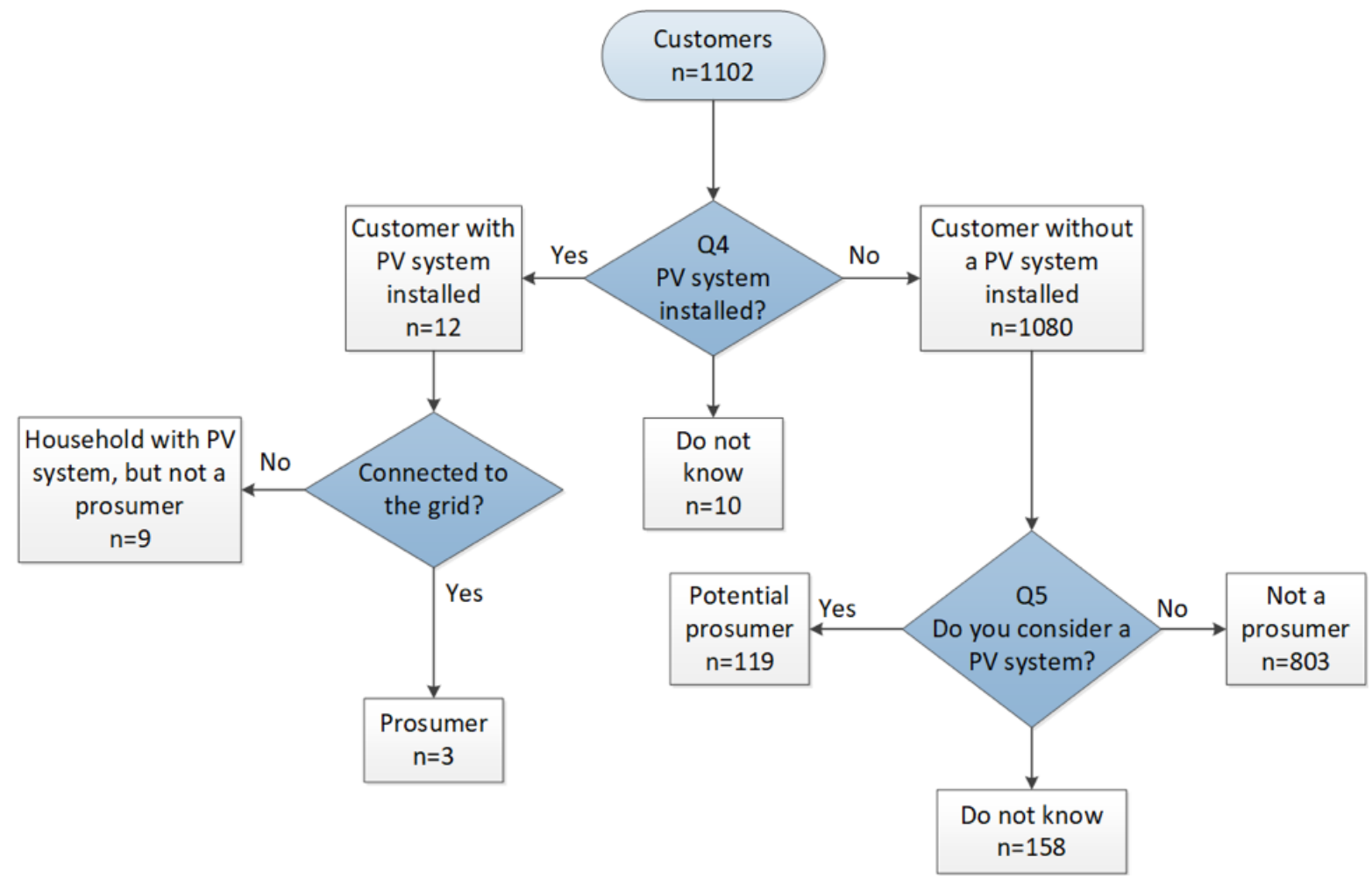

Figure 1. Flow chart of the survey and the number of respondents within each sub-group.

\section{Results}

Respondent background. We first get to know the respondents by reviewing their attitudes and knowledge about electricity consumption and production. Respondents have concern about their household electricity usage, with over half of respondents $(56.2 \%)$ indicated they were concerned or very concerned.

The numbers also show that respondents are knowledgeable about the energy sources that produce electricity. Most people knew hydropower generates nearly all electricity in Norway-about 95 percent [13]. Nearly two-thirds of respondents believe hydropower generates 70 to 100 percent of electricity, while less than 15 percent believe hydropower accounts for less than half of electricity production. Respondents also show an understanding of residential electricity consumption patterns. Respondents correctly identified that space heating accounts for a majority of electricity consumption (57\%). Forty-four percent of the respondents think that heating of tap water represent 10-29 percent of the electricity consumption, and nearly half (49\%) think cooking/white goods represents 10-29 percent of the electricity consumption. These perceptions correspond with a recent study that reported the share of electricity used for space heating, heating of tap water and cooling/white goods is 64,15 and 10 percent [13].

Barriers and Opportunities. Table 2 summarizes the prominent reasons for considering and not considering a PV system. Among those that have not considered a system, the three most cited reasons were the cost of the system
(35\%), the satisfaction with current system (29\%), and not knowing about the possibility of a solar system (26\%). Other noteworthy issues include uncertainty about the technology $(23 \%)$ and whether conditions are suitable (17\%).

Respondents that have considered installing a PV system most often attribute their interest to environmental concerns $(84 \%)$. About two-thirds of respondents indicate their interest is in saving on energy cost (68\%) and supporting the solar market (65\%). Other motives include an interest in the technology (55\%) and a desire to be independent from retailers $(54 \%)$.

Table 2. Factors affecting the consideration of a solar system.

\begin{tabular}{ll}
\hline $\begin{array}{l}\text { Not considered } \\
(\mathrm{n}=803)\end{array}$ & $\begin{array}{l}\text { Most important reasons for not considering a } \\
\text { solar system: Too expensive (35\%). Satisfied } \\
\text { with current system (29\%). Not aware of the } \\
\text { possibility (26\%). Concerns about the technology } \\
(23 \%) . \text { Unsure if conditions are suitable (17\%) }\end{array}$ \\
\hline $\begin{array}{l}\text { Considered, but } \\
\text { not installed } \\
(\mathrm{n}=119)\end{array}$ & $\begin{array}{l}\text { Most important reasons in considering a solar } \\
\text { system: Contribute to better environment }(84 \%) . \\
\text { Save money on energy cost }(68 \%) . \text { Support } \\
\text { market for solar }(65 \%) . \text { Interest in experiencing } \\
\text { the technology (55\%). Independence from } \\
\text { electricity retailer }(54 \%)\end{array}$ \\
\hline
\end{tabular}

Willingness to Pay (WTP). To estimate the total household value of a residential PV system, we employ the contingent valuation method described in section four. We first 
review the responses to the dichotomous choice referendum question on respondent participation in a hypothetical Prosumer Electricity Program. Table 3 reports responses by bid amount. The numbers show the rate of 'yes' responses decline as the bid amount increases. This is consistent with the law of demand and provides us confidence in the internal consistency of the data. With a cost of 20,000 NOK, nearly half of respondents (46\%) are willing to install a solar system. As the bid increases to 40,000 and 60,000 , the rate of positive responses fell to 31 and 26 percent. The table also shows that the numbers indicate less certainty in the 'yes' responses than the 'no' responses.

Table 3. WTP responses by bid amount.

\begin{tabular}{lllll}
\hline $\begin{array}{l}\text { Bid } \\
\text { Amount } \\
\text { (NOK) }\end{array}$ & Response & $\#$ & $\%$ & Certainty \\
\hline 20,000 & Yes & 121 & 46 & 3.9 \\
& No & 68 & 26 & 8.3 \\
& Don't Know & 76 & 29 & - \\
40,000 & Yes & 82 & 31 & 4.2 \\
& No & 113 & 42 & 8.2 \\
& Don't Know & 74 & 28 & - \\
60,000 & Yes & 69 & 26 & 4.0 \\
& No & 114 & 42 & 8.4 \\
& Don't Know & 86 & 32 & - \\
\hline
\end{tabular}

To estimate household willingness to pay, we use a multinomial logit model to estimate the probability of a 'yes' response to the referendum question. Willingness to pay is estimated from the censored logit coefficients $[20,30]$. Table 4 reports the estimated mean willingness to pay to install a solar system. The numbers indicate that, on average, Norwegian households are willing to pay 9,280 NOK for an installation ( $p=0.190)$. Though statistically insignificant due to unexpectedly large standard errors, the estimate and confidence interval offers useful insights on willingness to pay. This value represents approximately a 12 percent of the full cost of an installation, which suggests that non-use values are insufficient to move households to install residential PV systems. The minimal impact of non-use values is likely unique to Norway, which already receives much of their electricity from renewable sources (hydro)-i.e., the status quo already provides non-use benefits. Therefore, generous support programs may be needed to increase residential PV installed capacity [31]. Currently, the main nationwide program in Norway (via Enova) provides up to 35 percent of the total invested amount [32]. In 2014-2017 the city of Oslo had its own support program, subsidizing up to 40 percent of the investment costs for residential PV panels [33]. Based on the willingness to pay from the survey, today's support scheme appears insufficient to achieve significant increases in PV prosumer systems.
Table 4. Estimated individual household WTP.

\begin{tabular}{lll}
\hline Estimated WTP & Standard Error & $\begin{array}{l}\text { 95\% Confidence } \\
\text { Interval }\end{array}$ \\
\hline 9,180 & 6,989 & {$[-4519,+22,880]$} \\
\hline
\end{tabular}

Table 5. Factors affecting respondent willingness to pay (WTP).

\begin{tabular}{ll}
\hline WTP = Yes & $\begin{array}{l}\text { Reasons for being willing to pay: Save money on } \\
\text { energy cost }(68 \%) . \text { Contribute to better } \\
\text { environment }(58 \%) . \text { Interest in experiencing the } \\
\text { technology }(23 \%) \text {. Independence from electricity } \\
\text { retailers (22\%). Support market for solar }(19 \%)\end{array}$ \\
\hline WTP = No & $\begin{array}{l}\text { Reasons for not being willing to pay: Housing } \\
\text { unit conditions are unsuitable }(40 \%) \text {. Norway } \\
\text { conditions are unsuitable (33\%). Insecure about } \\
\text { technology (29\%). Uncertainty in regulatory } \\
\text { conditions (22\%). Uncertainty in support }(20 \%)\end{array}$ \\
\hline
\end{tabular}

Recall that respondents who would (would not) sign up at the bid amount were asked for the most important reason why. Table 5 summarizes these reasons. The most popular reasons for being willing to pay the bid amount includes saving money on energy cost (68\%), contributing to the environment (58\%), and an interest in the technology (23\%). The most popular reasons for not being willing to pay include their housing unit being unsuitable (40\%), Norway not having suitable conditions (33\%), and insecurities about the technology (29\%).

\section{Summary and Discussion}

Herein we report findings from a stated-choice study on Norwegian household knowledge, attitudes and willingness to pay for residential PV systems. Findings show that, at the time, the vast majority of households had not considered installing a residential PV system. The main reasons for the lack of consideration include concerns about the cost, being happy with current power system, and not knowing about the possibility to become a prosumer. The existing reliance on low-cost, environmentally-friendly hydro power undercuts the environmental concerns that prompt consumer interest in other countries. The willingness to pay analysis revealed, as expected, households are sensitive to the cost of a residential PV system-lower prices led to people being more willing to install a PV system. Estimates of the average willingness to pay indicate that interest in residential PV is driven by more than financial concerns. Results therefore suggest that meaningful growth in residential PV capacity in Norway depends greater knowledge among households, continued advances in technology, clarity with the grid tariff, and stronger support systems. The recent surge in Norway's PV capacity followed improvements in 
regulatory rules and support programs, which reinforces the importance to leverage public interest and support programs. This corresponds to the experience from Denmark that show the important role that customer knowledge and support programs has on the development of residential PV and prosumers.

The deployment of residential PV systems in Norway has lagged other Scandinavian countries such as Denmark and Sweden, even though the solar irradiance can be similar. Many interconnected factors underlie the lack of activity, including the country's existing reliance on renewable energy resources, low electricity prices, and less aggressive support systems for PV.Despite Norway's current satisfaction, $\mathrm{PV}$ and prosumer development can transform the landscape for electricity and society. Neighborhoods could have local grids that allow residents to feed in their PV generation and become engaged participants that determine energy solutions for their neighborhoods. Rather than passively consuming electricity from a distant generator, people are active participants in a collective action that can lead to more reliable, fair and environmentally friendly electricity supply. Indeed, the social aspect of growing prosumer activity can yield transformative developments in the collective efforts to address environmental challenges related to energy.

Results from this study, as well as the literature, highlight that residential PV and prosumer development requires sufficient incentives, regulation clarity and public awareness.
The task is a bit tougher in Norway, where there is complacency with the current reliable, low-cost, renewable generation. However, even in Norway, improvements in programs and regulation led to a surge in residential PV development. Moving forward, there remains untapped potential in Norway and beyond. The emergence of green certificate programs cast a wider net than meeting domestic electricity demand, and support schemes, including the green certificate programs, can be modified to better support residential prosumers. Further development of residential PV and prosumers may be possible with new business models that introduce leasing PV systems. Also, there is room for additional improvements in regulatory structures. For instance, despite Norway's 2017 reforms, there remains ambiguity with its grid tariff because changes from an energy based to a capacity-based grid tariff, where customers pay according to how their consumption and generation affect the distribution grid, will influence the incentives within the PV market.

\section{Acknowledgments}

The authors appreciate helpful comments from David McEvoy, Shue Anderson, Mike McKee, Steffen Kallbekken and seminar participants at Emory University. Funding for this study was provided by the Norwegian Research Council ENERGIX Program.

\section{References and Notes}

[1] Masson G, Kaizuka I. Trends 2017 in Photovoltaic Applications-Survey Report of Selected IEA Countries between 1992 and 2016. Technical Report IEA PVPS T1-32: 2017, International Energy Agency; 2017.

[2] IEA. Trends 2016 in Photovoltaic Applications. 2016;Available from: http://iea-pvps.org/fileadmin/dam/public/report/national/Trends_ 2016_-_mr.pdf.

[3] Couture T, Barbose G, Jacobs D, Parkinson G, Chessin E, Belden A, et al. Residential Prosumers: Drivers and Policy Options (ReProsumers); 2014. doi:10.2172/1163237.

[4] Stoutenborough JW, Beverlin M. Encouraging Pollution-Free Energy: The Diffusion of State Net Metering Policies. Social Science Quarterly. 2008;89(5):1230-1251. doi:10.1111/j.1540-6237.2008.00571.x.

[5] Electricity, Gas and District Heating Supply. Statistics Sweden (SCB); 2016. Available from: http://www.scb. se/contentassets/32c099cd9dab4db8999acc5e4401c871/ en0105_2016a01_sm_en11sm1701.pdf.

[6] The Norwegian Water Resources and Energy Directorate. Solenergi (In Norwegian - Translated to "Solar energy"). Available from: https://www.nve.no/energiforsyning/kraftproduksjon/solkraft/.

[7] The Norwegian Water Resources and Energy Directorate. Plusskunder," (In Norwegian - Translated to "Prosumers"). Available from: https://www.nve.no/reguleringsmyndigheten/nettjenester/ nettleie/tariffer-for-produksjon/plusskunder/.

[8] Sæle H, Bremdal BA. Economic Evaluation of the Grid Tariff for Households with Solar Power Installed. CIRED - Open Access Proceedings Journal. 2017;2017(1):2707-2710. doi:10.1049/oapcired.2017.0556.

[9] Whitehead JC, Cherry TL. Willingness to Pay for a Green Energy Pro-

gram: A Comparison of Ex-ante and Ex-post Hypothetical Bias mitigation Approaches. Resource and Energy Economics. 2007;29(4):247261. doi:10.1016/j.reseneeco.2006.10.001.

[10] Poe GL, Clark JE, Rondeau D, Schulze WD. Provision Point Mechanisms and Field Validity Tests of Contingent Valuation. Environmental and Resource Economics. 2002;23(1):105-131. doi:10.1023/A:1020242907259.

[11] Mitchell R, Carson R. Using Surveys to Value Public Goods. Resources for the Future. Washington, DC. 1989;.

[12] Cummings RG, Harrison GW, Rutström EE. Homegrown Values and Hypothetical Surveys: Is the Dichotomous Choice Approach Incentive Compatible? The American Economic Review. 1995;85(1):260-266.

[13] Energy Consumption in Households, 2012. Statistics Norway (SSB); 2017. Available from: https://www.ssb.no/en/energi-og-industri/ statistikker/husenergi.

[14] Hanemann WM. Valuing the Environment Through Contingent Valuation. Journal of Economic Perspectives. 1994;8(4):19-43. doi:10.1257/jep.8.4.19.

[15] Carson RT. Contingent Valuation: A User's Guide. Environmental Science \& Technology. 2000;34(8):1413-1418. doi:10.1021es990728j.

[16] El-produksjon (In Norwegian - Translated to "Distributed generation"). Enova; 2018. Enova SF is a public agency, owned by the Ministry of Petroleum and Energy. Available from: https: //www.enova.no/privat/alle-energitiltak/solenergi/el-produksjon-/.

[17] Inderberg TH, Tews K, Turner B. Is there a Prosumer Pathway? Exploring Household Solar Energy Development in Germany, Norway, and the United Kingdom. Energy Research \& Social Science. 2018;42. doi:10.1016/j.erss.2018.04.006.

[18] Throndsen W, Ryghaug M, Skjølsvold TM, Haunstrup Christensen T. From Consumer to Prosumer. Enrolling Users into a Norwegian PV Pilot. ECEEE Summer Study Proceedings. 2011;(9). Avail- 
able from: https://www.eceee.org/library/conference_proceedings/ eceee_Summer_Studies/2017/9-consumption-and-behaviour/fromconsumer-to-prosumer-enrolling-users-into-a-norwegian-pvpilot/2017/9-127-17_Throndsen.pdf/.

[19] Su W, Liu M, Zeng S, Streimikiene D, Balezentis T, AlisauskaiteSeskiene I. Valuating Renewable Microgeneration Technologies in Lithuanian Households: a Study on Willingness to Pay. Journal of Cleaner Production. 2018;191. doi:10.1016/j.jclepro.2018.04.199.

[20] Scarpa R, Willis K. Willingness-to-Pay for Renewable Energy: Primary and Discretionary Choice of British Households' for MicroGeneration Technologies. Energy Economics. 2010;32:129-136. doi:10.1016/j.eneco.2009.06.004

[21] Claudy M, Michelsen C, O'Driscoll A, Mullen M. Consumer awareness in the adoption of microgeneration technologies: An empirical investigation in the Republic of Ireland. Renewable and Sustainable Energy Reviews. 2010 09;14:2154-2160. doi:10.1016/j.rser.2010.03.028.

[22] Oberst C, Madlener R. Prosumer Preferences Regarding the Adoption of Micro-Generation Technologies: Empirical Evidence for German Homeowners. SSRN Electronic Journal. 2015;doi:10.2139/ssrn.2670035.

[23] Hanemann WM. Valuing the Environment Through Contingent Valuation. The Journal of Economic Perspectives. 1994;8(4):19-43.

[24] Carson RT. Contingent Valuation: A User's Guide. Enviromental Science \& Technology. 2000;34(8):1413-1418. doi:10.1021/es990728j.

[25] Whitehead J, Cherry T. Willingness to Pay for a Green Energy Pro- gram: A Comparison of Ex-ante and Ex-post Hypothetical Bias Mitigation Approaches. Resource and Energy Economics. 2007;29:247261. doi:10.1016/j.reseneeco.2006.10.001.

[26] Clark J, Poe G, Rondeau D, Schulze W. Provision Point Mechanisms and Field Validity Test of Contingent Valuation. Environmental \& Resource Economics. 2002;23:105-131. doi:10.1023/A:1020242907259.

[27] $100 \mathrm{NOK}=9.90$ Euro $=10.92$ USD on 11/22/2019.

[28] Mitchell RC, Carson RT. Using Surveys to Value Public Goods. Washington, DC, USA: Resources for the Future; 1989.

[29] Cummings RG, Harrison G, Rutstrom E. Homegrown Values and Hypothetical Surveys: Is the Dichotomous Choice Approach IncentiveCompatible? American Economic Review. 1995;85(1):260-266. Available from: https://EconPapers.repec.org/RePEc:aea:aecrev:v: 85:y:1995:i:1:p:260-66.

[30] Whitehead and Cherry provide details of the empirical model for this framework.

[31] The estimated total cost is for a PV system with installed capacity of $3 \mathrm{kWh}$, using the cost of $26,000 \mathrm{kNOK} / \mathrm{kWh}$ with an exchange rate of 1 EUR $=9.13$ NOK.

[32] The program is offered by Enova SF, an entity owned by the Norwegian Ministry of Petroleum and Energy, as part of their directive to reduced greenhouse gas emissions, develop energy and climate technology, and strengthen security of supply.

[33] The Oslo program cannot be combined with the nationwide program. 


\section{Appendix}

Survey Instrument (originally in Norwegian, translation using Google Translate)

\section{Q024: Single coded}

Not back. FROM THE PANEL: How many people usually live in your household when you count on all adults and children (including yourself)?.

$1-1$ person

$2-2$ people

$3-3$ people

$4-4$ people

$5-5$ or more people

\section{Q001: Single coded}

Not back. We start with some questions about your home, and then think of primary residence - not a holiday home or similar. How busy are you with household electricity consumption?. Normal.

1 - Very little busy

2 - Pretty little busy

3 - Neither little nor much busy

4 - Pretty much busy

5 - Very much busy

9999 ikke Don't know * Position fixed * Exclusive

Table A1. Q002: Matrix. About how much of the electricity produced in Norway do you think comes from the following sources? Normal.

\begin{tabular}{|c|c|c|c|c|c|c|c|}
\hline & Under $10 \%$ & $10-29 \%$ & $30-49 \%$ & $50-69 \%$ & $70-89 \%$ & $90-100 \%$ & Don't know \\
\hline Hydropower & - & - & - & - & - & - & - \\
\hline Fossil (coal, oil, gas) & - & - & - & - & - & - & - \\
\hline Nuclear & - & - & - & - & - & - & - \\
\hline Wind & - & - & - & - & - & - & - \\
\hline Solar & - & - & - & - & - & - & - \\
\hline Heat power from biofuel & - & - & - & - & - & - & - \\
\hline
\end{tabular}

Table A2. Q003: Matrix. Not back - Number of statements: 5- Number of Scales: 7. If a large proportion of the electricity consumed by an ordinary Norwegian household, do you think are used for the following purposes? Normal.

\begin{tabular}{|c|c|c|c|c|c|c|c|}
\hline & Under $10 \%$ & $10-29 \%$ & $30-49 \%$ & $50-69 \%$ & $70-89 \%$ & $90-100 \%$ & Don't know \\
\hline $\begin{array}{l}\text { Room Heating (panel, } \\
\text { heat pumps, floor, etc.) }\end{array}$ & - & - & - & - & - & - & - \\
\hline $\begin{array}{l}\text { Appliances (washing } \\
\text { machine, dishwasher, } \\
\text { dryer, etc.) }\end{array}$ & - & - & - & - & - & - & - \\
\hline $\begin{array}{l}\text { Electronics (TV, radio, PC, } \\
\text { etc.) }\end{array}$ & - & - & - & - & - & - & - \\
\hline Hot water heating & - & - & - & - & - & - & - \\
\hline Other & - & - & - & - & - & - & - \\
\hline
\end{tabular}




\section{Q004: Single coded}

Not back. Norwegian households have the opportunity to produce electricity themselves, by installing solar cell installations in the home (eg on the roof). The power can be used for own consumption or sold online. Suppliers to the network are often called "plus customers". Do you / you have solar cell installations in your home and supply electricity to the network (is plus customer)?. Normal.

1 - Have solar panels and supply power to the grid

2 - Have solar panels but do not supply power to the grid

3 - Do not have solar panels

9999 ikke Don't know * Position fixed * Exclusive

Ask only if Q004,3

B001: Do not have a solar cell system Begin block

\section{Q005: Single coded}

Not back. Are you considering installing solar cells?. Normal.

$1-$ Yes

$2-\mathrm{No}$

9999 ikke Don’t know * Position fixed * Exclusive

Ask only if Q005,2

B002: Does not consider installing facilities Start block

\section{Q006: Multi coded}

Not back $-\operatorname{Min}=1$. What are the most important reasons why you are not considering installing solar cells?. You can provide more answers. Normal.

1 - Do not know the opportunity

2 - The conditions in Norway are unsuitable for solar power production

3 - Happy with today's system

4 - Are uncertain about regulations and support schemes

5 - Unsure whether the technology will work satisfactorily

6 - Not sure how the systems are installed

7 - Not sure where I/ we can get information about the procedure

$8-$ Is too expensive

9 - Is too time-consuming to get

10 - The home is not suitable for solar installation

11 - Depends on others (eg, co-ownership / cohabitation) in order to make a decision

12 - Doubt that I / we get permission from the municipality for installation

13 - Doubt that my network company / ours will be positive to the power supply / offer plus agreement

14 - Uncertain about the environmental impact

9997 - Other, notes ... * Open * Position fixed

9999 ikke Don't know * Position fixed * Exclusive

\section{Q007: Single coded}

Now imagine that purchasing and installing a photovoltaic system will cost you kr. 20,000. You can use some of the power yourself and sell the rest to the web. Normal.

$1-$ Yes

$2-$ No 
9999 ikke Don't know * Position fixed * Exclusive

Ask only if Q007.1

B003: Still considering installation Begin block

\section{Q008: Single coded}

Not back. How certain or uncertain are you to install solar panels?. Normal.

$1-1$. Very uncertain

$2-2$

$3-3$

$4-4$

$5-5$

$6-6$

$7-7$

$8-8$

$9-9$

$10-10$ Very safe

\section{Q009: Multi coded}

Not back - Min $=1$. What are the main reasons why you want to install solar panels?. You can provide more than one answer. Normal.

1 - Interest in the technology

2 - Want to gain your own experience with the technology

3 - Want to reduce future electricity costs

4 - Want to contribute to a better environment

5 - Want the solar cell market to grow

6 - Want greater independence from central power suppliers

9997 - Other, notes ... * Open * Position fixed

9999 ikke Don't know * Position fixed * Exclusive

Table A3. Q010: Matrix. Not back - Number of statements: 6 - Number of Scales: 6. How good or bad do you know about the following conditions regarding the installation of solar panels? Normal.

\begin{tabular}{llllll}
\hline & Very bad & bad & neutral & good & Very good \\
\hline Operation & - & - & - & - & - \\
Reliability & - & - & - & - & - \\
Production & - & - & - & - & - \\
$\begin{array}{l}\text { The time of day/year } \\
\text { when available }\end{array}$ & - & - & - & - \\
$\begin{array}{l}\text { The financial profitability } \\
\text { of the investment }\end{array}$ & - & - & - & - \\
Regulatory framework & - & - & - & - \\
\hline
\end{tabular}

B003: Still considering installation End block

Ask only if Q007,9999

B005: Still uncertain about investment Begin block 


\section{Q012: Multi coded}

Not back - Min $=1$. What is the significance of the following factors for your uncertainty when it comes to installing solar panels?. You can provide more than one answer. Normal.

I'm not sure ...

1 - if conditions in Norway are suitable for own electricity production

2 - framework conditions for plus customers in the future (regulations, support schemes, prices)

3 - if the technology will work satisfactorily

4 - where I / we can get information about the procurement

5 - the possibility of getting support

6 - the reliability of the systems

7 - how the systems are installed

8 - how long the procurement takes

9 - if the home is suitable for installation

10 - if installation is possible / allowed where I / we live

11 - if I / we would get installation permission from the municipality

12 - if my network company / ours is positive to receive power (offers plus agreement)

13 - at the system's environmental effect

9997 - Other, notes ... * Open * Position fixed

9999 ikke Don't know * Position fixed * Exclusive

B005: Still uncertain about investment End block

Ask only if Q007,2

B004: Will still not invest Begin block

\section{Q011: Single coded}

Not back. How certain or uncertain are you not to install solar panels?. Normal.

$1-1$. Very uncertain

$2-2$

$3-3$

$4-4$

$5-5$

$6-6$

$7-7$

$8-8$

$9-9$

10 - Very safe

\section{Q028: Multi coded}

Not back - Min $=1$. What significance does the following have for you / you do not want to install solar panels at a cost of NOK. 20,000?. You can provide more than one answer. Normal.

I / we are unsure of ...

1 - if conditions in Norway are suitable for own electricity production

2 - framework conditions for plus customers in the future (regulations, support schemes, prices)

3 - if the technology will work satisfactorily

4 - where I / we can get information about the procurement

5 - the possibility of getting support

6 - the reliability of the systems 
7 - how the systems are installed

8 - how long the procurement takes

9 - if the home is suitable for installation

10 - if installation is possible / allowed where I / we live

11 - if I / we would get installation permission from the municipality

12 - if my network company / ours is positive to receive power (offers plus agreement)

13 - at the system's environmental effect

9997 - Other, notes ... * Open * Position fixed

9999 ikke Don't know * Position fixed * Exclusive

B004: Will still not invest End block

B002: Don't consider installing facilities End block

Ask only if Q005.1

B007: Potential plus customer Begin block

Q023: Multi coded

Not back - Min = 1. Through which channel (s) did you / you have gained knowledge about the possibility of installing solar cell installations?. You can provide more answers. Normal .

1 - Neighbors

2 - Family / friends / colleagues

3 - People I / we know in the industry

4 - Advertisements

5 - Was consulted by supplier

6 - Was consulted by grid company / power company

7 igheter Authorities (Enova, the municipality, etc.)

8 ok Undertake own investigations (literature / internet search etc.)

9 - Other sources

9999 ikke Don't know * Position fixed * Exclusive

Q025: Single coded

Not back. When did you begin to consider installing solar cell installations?. Normal.

1 - Less than a year ago

$2-1-2$ years ago

$3-3-5$ years ago

4 - More than 5 years ago

9999 ikke Don't know * Position fixed * Exclusive 
Table A4. Q026: Matrix. Not back - Number of statements: 7 - Number of Scales: 6 . What is the significance of the following conditions for your desire to invest in solar power plants? Normal.

\begin{tabular}{lllllll}
\hline & Very small & small & neutral & big & Very big & Don't know \\
\hline Interest in technology & - & - & - & - & - & - \\
$\begin{array}{l}\text { Interest in experiencing } \\
\text { technology }\end{array}$ & - & - & - & - & - & - \\
$\begin{array}{l}\text { Potential savings on } \\
\text { future power costs }\end{array}$ & - & - & - & - & - & - \\
$\begin{array}{l}\text { Contributing to better } \\
\text { environment }\end{array}$ & - & - & - & - & - & - \\
$\begin{array}{l}\text { Support development of } \\
\text { solar }\end{array}$ & - & - & - & - & - & - \\
$\begin{array}{l}\text { Want independence from } \\
\text { central power }\end{array}$ & - & - & - & - & - & - \\
Other reasons, please & - & - & - & - & - & - \\
note & - & - & & & & \\
\hline
\end{tabular}

Table A5. Q027: Matrix. Not back - Number of statements: 9 - Number of Scales: 6. What knowledge do you have of the following conditions regarding the installation of solar power plants? Normal.

\begin{tabular}{|c|c|c|c|c|c|c|}
\hline & Very bad & bad & neutral & good & Very good & Don't know \\
\hline Operation & - & - & - & - & - & - \\
\hline Reliability & - & - & - & - & - & - \\
\hline Installation Needs & - & - & - & - & - & - \\
\hline Prosumers & - & - & - & - & - & - \\
\hline Production Potential & - & - & - & - & - & - \\
\hline $\begin{array}{l}\text { Solar potential over the } \\
\text { year }\end{array}$ & - & - & - & - & - & - \\
\hline $\begin{array}{l}\text { Solar potential over the } \\
\text { day }\end{array}$ & - & - & - & - & - & - \\
\hline Financial profitability & - & - & - & - & - & - \\
\hline Regulatory framework & - & - & - & - & - & - \\
\hline
\end{tabular}

B007: Potential Plus Customer End Block

B001: Does not have a solar cell system End block

Ask only if Q004.1

B006: Begin block

\section{Q013: Multi coded}

Not back - Min $=1$. Through which channel $(\mathrm{s})$ did you / you receive information about solar cell installations, when you decided on the procurement? You can provide more than one answer. Normal.

1 - Neighbors

2 - Family / friends / colleagues

3 - People I/ we know in the industry

4 - Advertisements

5 - Was consulted by solar cell supplier

6 - Was consulted by network / power company

7 - Did own investigations (eg via the Internet, books, newspapers, etc.)

8 igheter Authorities (Enova, municipality, etc.) 
9997 - Other, notes ... * Open * Position fixed

9999 ikke Don't know * Position fixed * Exclusive

\section{Q014: Single coded}

Not back. About how long have you / you had solar panels?. Normal.

1 - Less than 1 year

$2-1-2$ years

$3-3-5$ years

4 - More than 5 years

9999 ikke Don't know * Position fixed * Exclusive

\section{Q015: Multi coded}

Not back. What was the main reason for installing solar cells?. You can provide more answers. Normal.

1 - Interested in the technology

2 - Jobs with related things - want experience

3 - Want to reduce future electricity costs

4 - Want to contribute to a better environment

5 - Want the solar cell market to grow

6 - Want greater independence from central power suppliers

9997 - Other, please note ... * Open * Position fixed

9999 ikke Don't know * Position fixed * Exclusive

Table A6. Q016: Matrix. Not back. In the process of acquiring and installing the solar cell plant, how unsatisfied or satisfied were you / you with information and follow-up from the following actors? If you have not been in contact with the player, click "Not relevant". Normal.

\begin{tabular}{lllllll}
\hline & $\begin{array}{l}\text { Very } \\
\text { Dissatisfied }\end{array}$ & $\begin{array}{l}\text { Pretty } \\
\text { Dissatisfied }\end{array}$ & $\begin{array}{l}\text { Pretty } \\
\text { Satisfied }\end{array}$ & Very Satisfied & Don't Know & Not Relevant \\
\hline Plant supplier & - & - & - & - & - & - \\
Network company & - & - & - & - & - & - \\
$\begin{array}{l}\text { Buyer (not network } \\
\text { company) }\end{array}$ & - & - & - & - & - & - \\
$\begin{array}{l}\text { Government Information } \\
\text { Government }\end{array}$ & - & - & - & - & - & - \\
$\begin{array}{l}\text { Communications } \\
\text { Government Financial }\end{array}$ & - & - & - & - & - & - \\
$\begin{array}{l}\text { Support } \\
\text { Other, please specify }\end{array}$ & - & - & - & - & - \\
\hline
\end{tabular}


Table A7. Q017: Matrix. Not back - Number of statements: 11 - Number of Scales: 6. How dissatisfied or satisfied are you / you with the PV system, with regard to: Normal.

\begin{tabular}{lllllll}
\hline & $\begin{array}{l}\text { Very } \\
\text { Dissatisfied }\end{array}$ & $\begin{array}{l}\text { Pretty } \\
\text { Dissatisfied }\end{array}$ & Neutral & $\begin{array}{l}\text { Pretty } \\
\text { Satisfied }\end{array}$ & Very Satisfied & Don't Know \\
\hline Operation & - & - & - & - & - & - \\
Reliability & - & - & - & - & - & - \\
Installation Needs & - & - & - & - & - & - \\
Prosumers & - & - & - & - & - & - \\
Production Potential & - & - & - & - & - & - \\
$\begin{array}{l}\text { Solar potential over the } \\
\text { year }\end{array}$ & - & - & - & - & - & - \\
$\begin{array}{l}\text { Solar potential over the } \\
\text { day }\end{array}$ & - & - & - & - & - & - \\
Financial profitability & - & - & - & - & - & - \\
Regulatory framework & - & - & - & - & - & - \\
\hline
\end{tabular}

\section{Q018: Single coded}

Not back. Given the experience you have now, would you recommend others to install solar panels?. Normal.

$1-$ Yes

2 - No

9999 ikke Don't know * Position fixed * Exclusive

Ask only if Q024,2,3,4,5

\section{Q019: Matrix}

Not back - Number of statements: $4-$ Number of Scales: 6 . Who in the household is mainly responsible for the following conditions regarding the solar power plant?. Normal.

Myself Spouse / partner Children Others The responsibility is shared between several do not know.

\section{Q020: Single coded}

Not back. Did you / you count accurately on the solar cell plant's profitability?. Normal.

$1-$ Yes

$2-$ No

9999 ikke Don't know * Position fixed * Exclusive

\section{Q021: Single coded}

Not back. Do you suppose that the photovoltaic system will be repaid in its lifetime?. Normal.

$1-$ Yes

$2-\mathrm{No}$

9999 ikke Don't know * Position fixed * Exclusive

Ask only if Q021.1

\section{Q022: Numeric}

Not back - Max $=999$. How many years of repayment time does the plant have? 